\title{
PENGARUH KETELADANAN GURU TERHADAP PERILAKU SOSIAL SISWA SEKOLAH MENENGAH KEJURUAN (SMK)
}

\author{
Ria Nurbayiti ${ }^{1}$, Mahfud $^{2}$, Siti Maryam Munjiat ${ }^{3}$ \\ 1,2,3 Pendidikan Agama Islam (PAI) FITK IAIN Syekh Nurjati Cirebon \\ Email : ${ }^{1}$ rianurbayiti23@gmail.com, ${ }^{2}$ mahfud@syekhnurjati.ac.id, \\ ${ }^{3}$ siti.maryam.munjiat@syekhnurjati.ac.id \\ DOI: 10.29313 / tjpi.v8i1.5166
}

Accepted: September 25th, 2019. Approved: October 10th, 2019. Published: October 14th, 2019

\begin{abstract}
Abstrak
Exemplary means showing and giving a good example to the learners. Human as a social creature from the perspective of social learning theory views that human social behavior is a result of interaction between the influence of situation, individual behavior, cognitive and individual emotion. This study aims to get the data about The Influence of Teacher example on Students' Behavior at SMK AlHidayah Cirebon. This study applied Quantitative method. Methods and techniques of data collection this study are a questionnaire, interviews, observation, and documentation. Thus, the techniques of data analysis of this study use research instrument test, data analysis test using percentage formula, correlation, bypothesis test and coefficient of determination.
\end{abstract}

Keywords: Teacher Adherence; Social Behavior.

\begin{abstract}
Abstrak
Keteladanan adalah memberikan contoh yang baik kepada peserta didik. Manusia sebagai makbluke sosial dalam Perspektif teori belajar sosial memandang babwa suatu perilaku sosial manusia, merupakan hasil dari saling interaksi antara pengaruh situasi, perilaku individu, kognitif, dan emosi individu Penelitian ini bertujuan untuk memperoleh data tentang Pengarub Keteladanan Guru Terhadap Perilaku Sosial Siswa Sekolah Menengah Kejuruan (SMK) Al-Hidayah Kota Cirebon. Metode penelitian ini menggunakan pendekatan kuantitatif. Penelitian ini di lakukan di Sekolah Menengah Kejuruan (SMK) Al-Hidayah Kota Cirebon. Teknik pengumpulan data yang digunakan sebagai berikut: angket, wawancara, observasi, dan dokumentasi. Adapun teknik analisis data yang digunakan adalah uji instrumen penelitian, dan uji analisis data menggunakan rumus prosentase, korelasi, uji hipotesis dan koefisien determinasi.
\end{abstract}

Kata Kunci: Ketaladanan Guru; Perilaku Sosial. 


\section{PENDAHULUAN}

Dalam perkembangan dan kemajuan suatu bangsa, pendidikan ternyata memiliki peran yang sangat penting di dalamnya. Dalam konteks ini guru merupakan acuan dari keberhasilan suatu pendidikan. Oleh sebab itu menjadi seorang guru, tentunya harus memiliki segudang kesabaran, keteladanan, serta setumpuk pengetahuan dalam menjalankan profesi tersebut. ${ }^{1}$

Suatu pendidikan tentunya tidak akan mencapai suatu keberhasilan apabila tidak ada peranan guru di dalamnya, yang terus menerus berusaha dalam mewujudkan gagasan, ide, pemikiran dalam bentuk prilaku dan sikap yang terbaik dalam tugasnya sebagai seorang pendidik. ${ }^{2}$

Menjadi guru adalah pekerjaan yang mulia. segala perilakunya di contoh dan ditiru oleh peserta didik. Banyak sekali jasa yang sudah diberikan untuk kemajuan bangsa ini, sehingga guru efektif adalah guru yang menunaikan peran, tugas, dan fungsinya secara profesional. Sebagai teladan, guru tidak hanya mengajar (instructor) secara tepat dan efektif, tetapi juga harus efektif dalam mendidik (educator). Mendidik dengan sebuah keteladanan itu lebih efektif dan lebih baik daripada mengajar hanya dengan perkaataan saja (lisan al-hal ashahu min lisan al-maqal). ${ }^{3}$

Mengenai hal ini, berdasarkan hasil wawancara dan observasi yang peneliti lakukan yang berkaitan dengan Keteladanan Guru di Sekolah Menengah

$1 \quad$ Zahroh, Aminatul.Membangun Kualitas Pembelajaran Melalui Dimensi Profesionalisme Guru. (Bandung: Penerbit Yrama Widya, 2015). Hlm. 1

2 Drajat, Manpan dan Ridwan Effendi. Etika Profesi Guru. (Bandung: Alfabeta,2014). Hlm. 46

3 Zahroh, Aminatul. Membangun Kualitas Pembelajaran Melalui Dimensi Profesionalisme Guru. (Bandung: Penerbit Yrama Widya,2015). Hlm. 178
Kejuruan (SMK) Al-Hidayah, menyatakan bahwa guru disekolah tersebut sudah termasuk dalam kategori guru yang cukup teladan, seperti memberikan contoh yang baik pada siswa dalam perbuatan maupun dalam perkataanya. Akan tetapi menurut Bapak Khulwani selaku guru Pendidikan Agama dan Budi Pekerti mengatakan bahwa, rata-rata siswa kelas XI Sekolah Menengah Kejuruan (SMK) Al-Hidayah ternyata masuk dalam tahap perkembangan dan pertumbuhan. Siswa masih belum bisa mengontrol dirinya dalam hal emosional, sikap, maupun perlakuannya terhadap orang lain.

Hal ini ditunjukan dengan perilaku sosial siswa pada saat siswa berada di lingkungan sekolah, yaitu masih adanya siswa yang belum bisa menghormati sesamanya atau temannya, masih adanya siswa yang bolos sekolah atau pulang belum pada waktunya, dan ada juga siswa yang belum memiliki tata krama dan sopan santun ketika sedang berinteraksi dengan guru di sekolah.

Berdasarkan latar belakang masalah yang dibahas di atas, peneliti merasa perlu untuk mengadakan suatu penelitian yang bertujuan untuk memperoleh data tentang Pengaruh Keteladanan Guru Terhadap Perilaku Sosial Siswa Sekolah Menengah Kejuruan (SMK) Al-Hidayah Kota Cirebon.

Berdasarkan latar belakang masalah yang telah diuraikan di atas, maka terdapat beberapa pertanyaan penelitian, yaitu sebagai berikut: Apakah guru Pendidikan Agama Islam (PAI) kelas XI di Sekolah Menengah Kejuruan (SMK) AlHidayah Kota Cirebon termasuk seorang guru yang teladan? Apakah Perilaku Sosial Siswa kelas XI Sekolah Menengah Kejuruan (SMK) Al-Hidayah Kota Cirebon sudah baik ? Adakah Pengaruh Keteladanan Guru Terhadap Perilaku Sosial Siswa Sekolah Menengah Kejuruan (SMK) Al-Hidayah Kota Cirebon? 
Berdasarkan pertanyaan penelitian diatas, maka diperoleh tujuan penelitian sebagai berikut : Untuk Mengetahui keteladanan Guru Sekolah Menengah Kejuruan (SMK) Al-Hidayah Kota Cirebon; Untuk Mengetahui Perilaku Sosial Siswa kelas XI Sekolah Menengah Kejuruan (SMK) Al-Hidayah Kota Cirebon; dan Untuk Mengetahui Pengaruh Keteladanan Guru Terhadap Perilaku Sosial Siswa Sekolah Menengah Kejuruan (SMK) Al-Hidayah Kota Cirebon.

\section{LANDASAN TEORI}

Keteladanan adalah memberikan contoh yang baik kepada peserta didik, baik dalam ucapan maupun perbuatan. ${ }^{4}$

Perilaku Sosial adalah kegiatan yang berhubungan dengan orang lain, kegiatan yang berkaitan dengan pihak lain, yang memerlukan sosialisasi dalam hal bertingkah laku yang dapat diterima oleh orang lain, serta upaya mengembangkan sikap sosial yang layak diterima oleh pihak lain. ${ }^{5}$

\section{METODOLOGI PENELITIAN}

\section{Teknik Pengumpulan Data}

a. Kuesioner atau Angket

Kuesioner berasal dari bahasa

Latin: Questionnaire, yang artinya adalah serangkaian pertanyaan yang berhubungan dengan topik tertentu yang diberikan kepada sekelompok individu yang bertujuan untuk memperoleh suatu data. ${ }^{6}$ Teknik angket ini digunakan untuk memperoleh data tentang variabel $\mathrm{X}$ yaitu Keteladanan Guru dan Variabel Y yaitu Perilaku Sosial, dilakukan dengan cara

4 Syahidin. Menelusuri Metode Pendidikan Dalam AlQuran. (Bandung: Alfabeta, 2009) Hlm. 150

5 Susanto, Ahmad. Perkembangan Anak Usia Dini. (Jakarta: Kencana, 2011). Hlm. 137

${ }^{6}$ Yusuf, Muri. Metode Penelitian Kuantitatif, Kualitatif dan Penelitian Gabungan. (Jakarta: Kencana, 2014). Hlm. 199 membagikan lembaran yang berisikan beberapa pernyataan dengan jawaban yang sudah tersedia, pihak yang diberi angket adalah responden yaitu siswa kelas XI TKJ 1 , angket yang digunakan penulis adalah angket tertutup, angket ini mengandung 25 butir item pernyataan.

b. Wawancara

Wawancara adalah suatu tanya jawab yang bertujuan untuk memberikan deskripsi dan orientasi awal periset perihal masalah dan subjek yang dikaji. ${ }^{7}$ Metode ini digunakan untuk mendapatkan data yang berkaitan keteladanan guru terhadap perilaku sosial siswa. Metode ini digunakan untuk memperoleh data pendapat bidang kurikulum, guru mata pelajaran PAI dan siswa. Dalam hal ini peneliti mengadakan interview atau tanya jawab terstruktur yang sifatnya terbuka, dengan beberapa pihak atau narasumber di Sekolah Menengah Kejuruan (SMK) AlHidayah Kota Cirebon.

\section{c. Observasi}

Teknik pengumpulan data dengan observasi digunakan bila, penelitian berkenaan dengan perilaku manusia, proses kerja, gejala-gejala alam dan bila responden yang di amati tidak terlalu besar. Dari segi proses pelaksanaan pengumpulan data, observasi dapat dibedakan menjadi participant observation (observasi berperan serta) dan non participant observation (observasi tidak berperan serta). ${ }^{8}$ Tujuan observasi ini ialah untuk menggunakan data dengan pengamatan secara langsung di lapangan. Sementara itu Observasi dalam proses pelaksanaan penelitian ini menggunakan observasi non partisipan, yakni penelitian yang tidak terlibat dan hanya sebagai pengamat independen mengenai Keteladanan Guru Pendidikan Agama dan

\footnotetext{
7 Salim, Agus. Teori Dan Paradigma Penelitian Sosial. (Yogyakarta: Penerbit Tiara Wacana, 2006). Hlm. 17

8 Sugiyono. Metode Penelitian Kuantitatif, Kualitatif, dan R\&D. (Bandung: Alfabeta, 2017). Hlm. 145
} 
Budi Pekerti (PABP) Sekolah Menengah Kejuruan (SMK) Al Hidayah Kota Cirebon. Sehingga dengan ini di harapkan akan dapat di ketahui lebih jauh dan lebih jelas bagaimana Pengaruh Keteladanan Guru Terhadap Perilaku Sosial Siswa Sekolah Menengah Kejuruan (SMK) Al Hidayah Kota Cirebon,

\section{d. Dokumentasi}

Dokumentasi merupakan catatan atau karya seseorang tentang apa yang ia teliti, yaitu dokumen tentang orang atau sekelompok orang, Peristiwa, atau Kejadian dalam situasi sosial yang sesuai dan terkait dengan fokus penelitian adalah sumber informasi yang sangat berguna dalam Penelitian. Dokumen ini dapat berbentuk teks tulis, artefacts, gambar, maupun foto. ${ }^{9}$ Metode ini digunakan untuk mendokumentasikan tentang administrasi kegiatan sekolah, serta memperoleh data tentang profil sekolah, struktur organisasi, sarana prasarana, jumlah guru dan siswa di SMK Al-Hidayah Kota Cirebon.

\section{Teknik Analisis Data}

a. Uji Instrumen Penelitian

1) Uji Validitas

Validitas berasal dari kata validity

artinya ketetapan, kecermatan, handal sedang secara istilah adalah instrumen penelitian dapat digunakan untuk mengukur sesuai fungsinya apa yang seharusnya diukur. Uji validitas ini digunakan untuk mengetahui kelayakan butir-butir (item-item) pertanyaan maupun pernyataan instrument penelitian baik berupa angket maupun skala sikap/likert. 10

2) Uji Reliabilitas

Menurut Mehrens dan Lehmann dalam buku Metodelogi Penelitian Pendidikan, Reliabilitas berasal dari kata

9 Yusuf, Muri. Metode Penelitian Kuantitatif, Kualitatif dan Penelitian Gabungan. (Jakarta: Kencana, 2014). Hlm. 391

10 Subur. Statistik Manual dan SPSS. (Cirebon: Eduvision, 2019). Hlm. 43 reliability yang berasal dari kata rely yang berarti percaya dan reliabel yang berarti bisa dipercaya. Keterpercayaan merupakan derajat keajegan (consistency) hasil pengukuran pada objek yang sama. ${ }^{11}$

3) Uji Normalitas

Pengujian Normalitas data digunakan untuk menguji apakah data kontinu berdistribusi normal sehingga analisis dengan validitas, reliabilitas, uji t, korelasi, regresi dapat di laksanakan. ${ }^{12}$

b. Analisis Data Angket

1) Prosentase

Untuk memperoleh frekuensi relatife (angka persenan), digunakan rumus :

$$
P=\frac{f}{N} X 100 \%
$$

Keterangan :

$\mathrm{f}=$ frekuensi yang sedang dicari persentasenya

$\mathrm{N}=$ Number of Cases (jumlah frekuensi/banyaknya individu)

$P=$ Angka Persentase. ${ }^{13}$

Untuk menilai skala presentase digunakan rumus sebagai berikut:
100\% : Seluruh responden
90\%-99\% : Hampir seluruhnya
$60 \%-89 \%$ : Sebagian besar
$51 \%-59 \% \quad$ : Lebih dari setengahnya
$50 \% \quad$ : Setengahnya
$40 \%-49 \% \quad$ : Hampir setengahnya
$20 \%-39 \% \quad$ : Sebagian kecil
$1 \%-19 \% \quad$ : Sedikit sekali
$0 \% \quad$ : Tidak ada

2) Uji Korelasi

Maka penulis menggunakan rumusan korelasi product moment sebagai berikut :

11 Kurniawan, Asep. Metode Penelitian Pendidikan. (Cirebon: Eduvision, 2018). Hlm. 106

12 Usman, Husaini dan Purnomo Setiady Akbar. Pengantar Statistika. (Jakarta: Pt Bumi Aksara, 2012). Hlm. 109

13 Sudijono, Anas. Pengantar Statistika Pendidikan. (Jakarta: Rajawali Pers, 2012). Hlm. 43 
$r_{x y}=\frac{N \sum x y-\left(\sum x\right)\left(\sum y\right)}{\sqrt{\left\{N \sum x^{2}-\left(\sum x\right)^{2}\right)\left(N \sum y^{2}-\left(\sum y\right)^{2}\right.}}$

Keterangan:

$\mathrm{r}_{\mathrm{xy}}$

"r" Product Moment

$\mathrm{N}$

: Number OfCases

$\sum X Y$

: Jumlah Hasil Perkalian

Antara Skor X Dan Skor Y

$\begin{array}{ll}\sum \mathrm{X} & : \text { Jumlah Seluruh Skor X } \\ \sum \mathrm{Y} & \text { : Jumlah Seluruh Skor Y }\end{array}$

3) Koefisien Determinasi (KD)

Rumus koefesien determinasi (KD), sebagai berikut:

$\mathrm{KD}=\left(\mathrm{r}_{\mathrm{xy}}\right)^{2} \mathrm{x} 100 \%$

Keterangan:

KD : Koefesien Determinasi

$\mathrm{r}_{\mathrm{xy}} \quad$ : hasil perhitungan korelasi, kemudian dikuadratkan

$100 \%$ : prosentase. ${ }^{14}$

Dalam hal ini, nilai $r_{x y}$ diartikan sebagai koefesien validasi, sehingga kriterianya menjadi:

$0,80-1,00 \quad:$ korelasi tinggi

$0,60-0,80 \quad:$ korelasi cukup

$0,40-0,60 \quad$ : korelasi sedang

$0,20-0,40 \quad:$ korelasi rendah

$0,00-0,20 \quad$ : korelasi sangat rendah

4) Uji Signifikansi

Uji signifikansi dilakukan dengan menggunakan rumus $t_{\text {tes }}$ atau $t_{\text {hitung }}$ sebagai berikut:

$$
t_{\text {hitung }}=\frac{r \sqrt{n-2}}{\sqrt{1-r^{2}}}
$$

Dimana :

$$
\begin{aligned}
& r=\text { Koefisien korelasi } \\
& n=\text { Banyaknya responden } \\
& \text { c. } \quad \text { Hipotesis }
\end{aligned}
$$

Dengan memperhatikan masalah-masalah diatas maka dapat dirumukan suatu hipotesis penelitian sebagai berikut:

$\mathrm{Ha}$ : Adanya Pengaruh Keteladanan Guru Terhadap Perilaku Sosial Siswa Sekolah Menengah Kejuruan (SMK) AlHidayah Kota Cirebon

Ho : Tidak ada Pengaruh Keteladanan Guru Terhadap Perilaku Sosial Siswa Sekolah Menengah Kejuruan (SMK) AlHidayah Kota Cirebon.

\section{Korelasi}

Setelah data terkumpul maka selanjutnya mencari Koefisien masingmasing variabel dengan menggunakan rumus korelasi product moment. Berdasarkan tabel di atas, maka dapat diketahui bahwa :

$$
\begin{aligned}
& \text { - } \mathrm{N}=39 \\
& \text { - } \sum \mathrm{X}=2857 \\
& \text { - } \sum \mathrm{Y}=3310 \\
& \text { - } \sum X Y=244047 \\
& \text { - } \sum \mathrm{X}^{2}=213993 \\
& \text { - } \sum \mathrm{Y}^{2}=283570 \\
& r_{x y}=\frac{N \sum x y-\left(\sum x\right)\left(\sum y\right)}{\sqrt{\left.\left\{N \sum x^{2}-\left(\sum x\right)^{2}\right\} N \sum y^{2}-\left(\sum y\right)^{2}\right\}}}
\end{aligned}
$$

$$
\begin{aligned}
& =\frac{39.244047-(2857)(3310)}{\sqrt{\left\{39 \sum 213993-(2857)^{2}\right\}\left\{39 \sum 283570-(3310)^{2}\right\}}} \\
& =\frac{9517833-9456670}{\sqrt{\sqrt{\{8345727-8162449\}}\{11059230-10956100\}}}
\end{aligned}
$$$$
=\frac{61163}{\sqrt{(183278)(103130)}}
$$$$
=\frac{61163}{\sqrt{18901460140}}
$$$$
=\frac{61163}{137482,581}
$$

Eduvision, 2019). Hlm. 62 
$=0,444878177$

$=0,445$

Berdasarkan hasil perhitungan diatas, diperoleh nilai sebesar $\mathrm{r}_{\mathrm{xy}}=0,445$, indeks tersebut menunjukan angka positif dan terletak pada interval $0,40-0,70$. Maka berdasarkan kriteria tersebut makna koefisien korelasinya termasuk dalam kategori korelasi yang Sedang atau Cukup. Sehingga dapat di interpretasikan bahwa terdapat hubungan antara Perhitungan korelasi product moment antara Keteladanan Guru Pendidikan Agama dan Budi Pekerti (PABP) (Variabel $\mathrm{x}$ ) terhadap Perilaku Sosial Siswa (Variabel Y) Sekolah Menengah Kejuruan (SMK) Al Hidayah Kota Cirebon.

\section{Koefisien Determinasi}

Kemudian dilakukan perhitungan koefisien determinasi untuk mengetahui berapa persen pengaruh antara Keteladanan Guru (variabel x) dengan Perilaku Sosial (variabel y), rumusnya sebagai berikut :

$$
\begin{aligned}
\mathrm{KD} \quad=\mathrm{r}^{2} \times 100 \% \\
=0,445^{2} \times 100 \% \\
=0,198025 \times 100 \% \\
=19,8025 \% \\
\quad \text { Hasil dari koefisien determinasi }
\end{aligned}
$$
diatas, menunjukan bahwa pengaruh Keteladanan Guru terhadap Perilaku Sosial siswa Sekolah Menengah Kejuruan (SMK) Al Hidayah Sebesar 19,8025\% dan sisanya $80,1975 \%$ dipengaruhi oleh faktor lain.

\section{Uji Signifikansi}

Hasil perhitungan korelasi belum berarti apa-apa sebelum dilakukan Uji Signifikansi atau Uji T. Dengan rumus :

$$
\begin{aligned}
& t_{\text {hitung }}=\frac{r \sqrt{n-2}}{\sqrt{1-r^{2}}} \\
& =\frac{0,445 \sqrt{39-2}}{\sqrt{1-0,445^{2}}}
\end{aligned}
$$

$$
\begin{aligned}
& =\frac{0,445 \sqrt{37}}{\sqrt{1-0,198025}} \\
& =\frac{(0,445)(6,08)}{\sqrt{1-0,198025}} \\
& =\frac{2,7056}{\sqrt{0,801975}} \\
& =\frac{2,7056}{0,895530569} \\
& =3,021 \\
& \text { Maka thitung }=3,021>t_{\text {tabel }}=1,697
\end{aligned}
$$

Keterangan hipotesis :

$\mathrm{H}_{0}=$ Tidak ada Hubungan yang Signifikan $\mathrm{H}_{\mathrm{a}}=$ Ada Hubungan yang Signifikan

Jika t hitung $>$ t tabel maka $\mathrm{H}_{0}$ ditolak dan $\mathrm{H}_{\mathrm{a}}$ diterima

Jika t hitung $<\mathrm{t}$ tabel maka $\mathrm{H}_{0}$ diterima dan $\mathrm{H}_{\mathrm{a}}$ ditolak. ${ }^{15}$

Setelah mengetahui t tabel di atas, maka $t_{\text {hitung }}=3,021>t_{\text {tabel }}=2,042$ ini berarti bahwa Jika nilai $\mathrm{t}$ hitung $>\mathrm{t}$ tabel, $\mathrm{H}_{0}$ ditolak dan $\mathrm{H}_{\mathrm{a}}$ diterima, artinya ada hubungan yang signifikan. Dengan demikian pengaruh (Variabel X) Keteladanan Guru Pendidikan Agama dan Budi Pekerti (PABP) terhadap (Variabel Y) Perilaku Sosial Siswa kelas XI TKJ 1 Sekolah Menengah Kejuruan (SMK) Al Hidayah Kota Cirebon adalah ada hubungan yang signifikan.

\section{Hipotesis Penelitian}

Adapun hipotesisi penelitian seperti yang telah dikemukakan dalam Bab 1 yaitu:

$\mathrm{Ha}$ : Adanya Pengaruh Keteladanan Guru terhadap Perilaku Sosial Siswa Sekolah Menengah Kejuruan (SMK) Al Hidayah Kota Cirebon adalah signifikan.

Ho : Tidak Adanya Pengaruh Keteladanan Guru terhadap

15 Subur. Statistik Manual dan SPSS. (Cirebon:

Eduvision, 2019). Hlm. 62 
Perilaku Sosial Siswa Sekolah Menengah Kejuruan (SMK) Al Hidayah Kota Cirebon adalah signifikan.

\section{PEMBAHASAN}

Sebagai teladan, guru tidak hanya mengajar (instructor) secara tepat dan efektif, tetapi juga harus efektif dalam mendidik (educator). Mendidik dengan keteladanan itu lebih efektif dan lebih baik daripada mengajar hanya dengan perkataan saja (lisan al-hal ashabu min lisan al-maqal). ${ }^{16}$. Menurut Bukhari Umar Keteladanan adalah memperlihatkan keteladanan atau memberikan contoh yang baik kepada peserta didik. Guru Pendidikan Agama Islam yang senantiasa bersikap baik kepada setiap orang, secara tidak langsung telah memberikan keteladanan bagi peserta ddik. Keteladanan pendidik kepada peserta didik merupakan faktor yang sangat penting dalam menentukan keberhasilan pembelajaran, karena seorang guru merupakan tokoh identifikasi dalam pandangan seorang peserta didik, yang akan dijadikan sebagai teladan dalam mengidentifikasikan diri dalam kehidupannya. ${ }^{17}$

Sebagaimana tertera dalam UU No. 14 Tahun 2005 tentang Guru dan Dosen (pasal 1; angka 1) disebutkan bahwa :"Guru adalah pendidik profesional dengan tugas untuk mendidik, mengajar, membimbing, mengarabkan, melatih, menilai, dan mengevaluasi peserta didik pada pendidikan anak usia dini, jalur pendidikan formal, pendidikan dasar, dan pendidikan menengah". ${ }^{18}$

16 Zahroh, Aminatul. Membangun Kualitas Pembelajaran Melalui Dimensi Profesionalisme Guru. (Bandung: Penerbit Yrama Widya, 2015). Hlm. 178

17 Umar, Bukhari. Hadis Tarbawi. (Jakarta: Amzah, 2016). Hlm. 187

18 Depdiknas. Undang-Undang Guru dan Dosen (UU RI No. 14 Th. 2005). (Jakarta: Sinar Grafika, 2016). Hlm. 3
Jika pendidik dan tenaga kependidikan menginginkan peserta didik untuk berperilaku dan bersikap sesuai dengan nilai-nilai karakter, maka pendidik dan ketenaga pendidikan yang lain adalah orang yang pertama memberikan contoh bagaimana berprilaku dan bersikap sesuai dengan nilai-nilai tersebut, misalnya : Berpakaian rapih, Datang tepat pada waktunya, Bekerja keras, Bertutur kata sopan, Kasih sayang, Perhatian terhadap peserta didik, Jujur, Menjaga kebersihan dan lain sebagainya. ${ }^{19}$

Sebagai seorang pendidik tentunya harus memberikan contoh yang baik pada peserta didik atau menjadi figur panutan, karena seorang pendidik tentunya akan menjadi tolak ukur bagi peserta didik dalam berperilaku. Sebagaimana dijelaskan dalam QS. Al-Ahzab ayat 21, yang artinya:

"Sesunggubnya telah ada pada (diri) Rasulullah itu suri teladan yang baik bagimu (yaitu) bagi orang yang mengharap (rahmat) Allah dan (kedatangan) hari kiamat dan dia banyak menyebut Allah."

Manusia sebagai makhluk sosisal dalam Perspektif teori belajar sosial memandang bahwa suatu perilaku sosial manusia, merupakan hasil dari saling interaksi antara pengaruh situasi, perilaku individu, kognitif, dan emosi individu. Para pakar belajar sosial, seperti Albert Bandura menyatakan bahwa perilaku sosial individu dipelajari dengan melakukannya dan secara langsung mengalami konsekuensi dari perilaku sosial. ${ }^{20}$

Perilaku pada dasarnya adalah suatu budi pekerti, dikarenakan arti dari budi pekerti sendiri secara hakiki adalah perilaku. ${ }^{21}$ Perilaku manusia termasuk perilaku sosialnya, merupakan hasil dari

19 Gunawan, Heri. Pendidikan Karakter. (Bandung: Alfabeta, 2012). Hlm. 92

${ }^{20}$ Hanurawan, Fattah. Psikologi Sosial. (Bandung: Pt Remaja Rosdakarya, 2012). Hlm. 8

21 Zuriah, Nurul. Pendidikan Moral \& Budi Pekerti Dalam Perspektif Perubahan. (Jakarta: Pt Bumi Angkasa, 2015). Hlm: 17 
interaksi karakteristik kepribadian individu dan lingkungan, kedua unsur tersebut tidak dapat terpisahkan satu sama lain dari kepribadian manusia. ${ }^{22}$

Perilaku sosial adalah kegiatan yang berhubungan dengan orang lain, kegiatan yang berkaitan dengan pihak lain, yang memerlukan sosialisasi dalam hal bertingkah laku yang dapat diterima oleh orang lain, serta upaya mengembangkan sikap sosial yang layak diterima oleh pihak lain. ${ }^{23}$

Indikator perilaku minimal yang dapat di kembangkan untuk jenjang SMU/MA/SMK ialah sebagai berikut : Meyakini adanya Tuhan Yang Maha Esa, Taat kepada ajaran agama, Memiliki toleransi, Memiliki rasa menghargai diri sendiri, Tumbuhnya disiplin diri, Berkembangnya etos kerja atau belajar, Memiliki rasa tanggung jawab, Memiliki rasa keterbukaan, Mampu mengendalikan diri, Mampu berfikir positif, Tumbuhnya potensi diri, Tumbuhnya cinta dan kasih sayang, Memiliki kebersamaan dan gotong royong, Memiliki kesetiakawanan, Memiliki sikap saling menghormati, Memiliki tata krama dan sopan santun, Memiliki rasa malu, Tumbuhnya kejujuran 24

Menjadi sosok seorang guru harus berusaha membawa perubahan tingkah laku peserta didiknya, bahwa pada dasarnya keteladanan dari seorang guru ternyata berdampak sekali pada pembentukan perilaku sosial peserta didik, hal ini sejalan dengan "teaching is the guidance of learning activities, teaching is for purpose of aiding the pupil learn" yang artinya bahwa mengajar itu memimpin aktivitas atau kegiatan belajar dan bermaksud untuk membantu atau menolong peserta didik

${ }^{22}$ Hanurawan, Fattah. Op.cit. Hlm. 10

23 Susanto, Ahmad. Perkembangan Anak Usia Dini. (Jakarta: Kencana, 2011). Hlm. 137

24 Zuriah, Nurul. Pendidikan Moral \& Budi Pekerti Dalam Perspektif Perubahan. (Jakarta: Pt Bumi Angkasa, 2015). Hlm: 71 dalam belajarnya. Peran dan tanggung jawab guru sebagai orang tua dan teladan sangat didukung oleh kepribadian guru itu sendiri. Misalnya, guru harus memiliki kejujuran yang tinggi, guru harus memiliki akhlak yang baik, guru harus bersifar pemaaf, toleran dan lain sebagainya. ${ }^{25}$

Jadi Keteladanan seorang guru sangat berpengaruh dalam peranan suatu pendidikan khususnya bagi pembentukan perilaku sosial siswa, karena seorang siswa atau anak didik tentunya tidak dapat membentuk perilaku sosialnya sendiri, mereka membutuhkan arahan dari seorang pendidik dalam menemukan karakter baik yang ada dalam dirinya, maka disinilah keteladanan seorang guru berperan.

Penelitian ini dilaksanakan di Sekolah Menengah Kejuruan (SMK) AlHidayah Kota Cirebon, Jl. Situgangga No. 165 Kalitanjung, Kelurahan Harjamukti, Kecamatan Harjamukti, Kota Cirebon.

Adapun waktu penelitian dilaksanakan selama 3 bulan, berdasarkan Surat Keputusan oleh Dekan Fakultas Ilmu Tarbiyah dan Keguruan (FITK) Nomor

0931/In.08/F.I.1/PP.009/02/2019

Terhitung mulai tanggal 02 Januari sampai dengan 31 Maret 2019. Penelitian ini di lakukan selama 3 bulan mulai tanggal 15 Februari sampai dengan 15 April 2019.

Sumber data primer adalah data yang hanya bisa peneliti dapatkan dari sumber pertama atau asli. Sumber data primer dapat diperoleh dari guru dan siswa Sekolah Menengah Kejuruan (SMK) Al Hidayah Kota Cirebon. Sumber data sekunder adalah data yang didapatkan bukan dari sumber pertama, tetapi peneliti mendapatkannya dari sumber kedua atau melalui perantara orang lain. ${ }^{26}$

25 Zahroh, Aminatul. Membangun Kualitas Pembelajaran Melalui Dimensi Profesionalisme Guru. (Bandung: Penerbit Yrama Widya, 2015). Hlm. 178

26 Kurniawan, Asep. Metode Penelitian Pendidikan. (Cirebon: Eduvision, 2018). Hlm. 176 
Jenis data yang digunakan dalam penelitian ini adalah bersifat kuantitatif. Data Kuantitatif merupakan data yang di simbolkan berupa angka atau bilangan, sehingga bisa diinput ke dalam skala pengukuran statistik. ${ }^{27}$

$$
\text { Populasi adalah wilayah }
$$

generalisasi yang terdiri atas: obyek/subyek yang mempunyai kualitas dan karakteristik tertentu yang ditetapkan oleh peneliti untuk dipelajari dan kemudian ditarik kesimpulannya. Jadi, Populasi bukan hanya orang, tetapi juga obyek dan benda-benda alam yang lain. Populasi juga bukan sekedar jumlah yang ada pada obyek/subyek yang dipelajari, tetapi meliputi seluruh karakteristik/sifat yang di miliki oleh subyek atau obyek itu. 28 Dalam penelitian ini yang menjadi populasi dari subyek penelitian ini adalah seluruh siswa kelas $\mathrm{X}$ yang terdiri dari 12 kelas yang berjumlah 400 siswa di Sekolah Menengah Kejuruan (SMK) Negeri 2 Kota Cirebon yakni :

\section{Jumlah Populasi}

Siswa-Siswi Kelas XI SMK Al Hidayah Kota Cirebon

Kelas XI

\begin{tabular}{llll}
\hline Kelas Rombel & \multicolumn{2}{c}{$\begin{array}{c}\text { Jenis } \\
\text { Kelamin }\end{array}$} & Jumlah \\
& L & $\mathbf{P}$ & \\
XI TKR 1 & 31 & 0 & 31 \\
XI TKR 2 & 32 & 0 & 32 \\
XI TKR 3 & 33 & 0 & 33 \\
XI TKJ 1 & 26 & 13 & 39 \\
XI TKJ 2 & 23 & 15 & 38 \\
XI AK & 2 & 34 & 36 \\
XI PBS & 10 & 24 & 34 \\
Jumlah & 157 & 86 & 243 \\
\hline
\end{tabular}

Sampel adalah bagian dari jumlah dan karakteristik yang dimiliki oleh populasi tersebut. Bila populasi besar, dan peneliti tidak mungkin mempelajari semua

${ }^{27}$ Kurniawan, Asep. Ibid. Hlm. 171

28 Sugiyono. Metode Penelitian Kuantitatif, Kualitatif, dan R\&D. (Bandung: Alfabeta, 2017). Hlm. 80 yang ada pada populasi misalnya karena keterbatasan dana, tenaga dan waktu, maka peneliti dapat menggunakan sampel yang diambil dari populasi itu. Apa yang dipelajari dari sampel itu, kesimpulannya akan dapat diberlakukan untuk populasi. Untuk itu sampel yang diambil dari populasi harus betul-betul representatif (mewakili). ${ }^{29}$ Penentuan sampel penelitian ini adalah sebagian siswa-siswi kelas XI yaitu 1 kelas Sekolah Menengah Kejuruan (SMK) Al-Hidayah Kota Cirebon.

\section{KESIMPULAN}

Berdasarkan hasil penelitian tentang Pengaruh Keteladanan Guru Terhadap Perilaku Sosial Siswa Sekolah Menengah Kejuruan (SMK) Al Hidayah Kota Cirebon, yang telah dilakukan dapat disimpulkan sebagai berikut : Keteladanan Guru Pendidikan Agama dan Budi Pekerti (PABP) (PAI) Sekolah Menengah Kejuruan (SMK) Al Hidayah Kota Cirebon termasuk dalam kategori Cukup dengan nilai $72 \%$ karena berada pada interval 55\%- 74\%.

Perilaku Sosial Siswa kelas XI TKJ 1 Sekolah Menengah Kejuruan (SMK) Al Hidayahh Kota Cirebon termasuk dalam kategori Baik dengan nilai 85\% karena berada pada interval 75\% - 100\%.

Berdasarkan hasil pengujian angket, terdapat pengaruh yang positif antara Keteladanan Guru Pendidikan Agama dan Budi Pekerti (PABP) (PAI) terhadap Perilaku Sosial Siswa kelas XI TKJ 1 Sekolah Menengah Kejuruan (SMK) Al Hidayahh Kota Cirebon, Selanjutnya dari perhitungan product moment, diperoleh nilai koefisien sebesar $r_{x y}$ $=$ 0,445 termasuk dalam kategori Sedang atau Cukup, dan terletak pada interval 0,40 - 0,70. Adapun besaran pengaruh Keteladanan Guru terhadap Perilaku

29 Sugiyono. Metode Penelitian Kuantitatif, Kualitatif, dan R\&D. (Bandung: Alfabeta, 2017). Hlm. 81 
Sosial siswa Sekolah Menengah Kejuruan (SMK) Al Hidayah sebesar 19,80\% dan sisanya $80,20 \%$, dan sisanya dipengaruhi oleh faktor lain yang tidak diteliti oleh peneliti seperti faktor keluarga atau lingkungan diluar sekolah. Adapun nilai uji $\mathrm{T}$ diperoleh $\mathrm{t}_{\text {hitung }}>\mathrm{t}_{\text {tabel }}$ atau $\mathrm{t}_{\text {hitung }}=3,021$ $>t_{\text {tabel }}=1,697$ sehingga di nyatakan adanya pengaruh yang signifikan.

Demikianlah hasil penelitian yang diperoleh oleh peneliti. Diharapkan pihak sekolah dan guru dapat memperhatikan kembali mengenai Keteladanan Guru, agar mampu meningkatkan Perilaku Sosial bagi peserta didik.

\section{DAFTAR PUSTAKA}

Drajat, Manpan \& Ridwan Effendi. (2014). Etika Profesi Guru. Bandung: Alfabeta.

Gunawan, Heri. (2012). Pendidikan Karakter. Bandung: Alfabeta.

Hanurawan, Fattah. (2012). Psikologi Sosial.
Bandung: PT Remaja Rosdakarya

Kurniawan, Asep. (2018). Metode Penelitian Pendidikan. Cirebon: Eduvision.

Salim, Agus. (2006). Teori Dan Paradigma Penelitian Sosial. Yogyakarta: Penerbit Tiara Wacana.

Susanto, Ahmad. (2011). Perkembangan Anak Usia Dini. Jakarta: Kencana.

Syahidin. (2009). Menelusuri Metode Pendidikan Dalam Al-Quran (Bandung: Alfabeta.

Umar, Bukhari. (2016). Hadis Tarbawi. Jakarta: Amzah.

Undang-Undang Guru dan Dosen (UU RI No. 14 Th. 2005). (2016). Jakarta: Sinar Grafika.

Zahroh, Aminatul. (2015). Membangun Kualitas Pembelajaran Melalui Dimensi Profesionalisme Guru. Bandung: Penerbit Yrama Widya.

Zuriah, Nurul. (2015). Pendidikan Moral \& Budi Pekerti Dalam Perspektif Perubahan. Jakarta: PT Bumi Aksara. 